\title{
Analisa SWOT Dalam Menentukan Strategi Bisnis Susu Murni Q-Milk
}

\author{
Kasmanto Miharja
}

AMIK BSI Bogor, kasmanto.kmm@bsi.ac.id

\begin{abstract}
ABSTRAK
Q-Milk adalah bisnis yang bergerak di bidang minuman segar dan sehat di daerah Cilodong Depok . Produk yang dihasilkan adalah susu murni Q-Milk dengan berbagai varian rasa tanpa bahan pengawet. Dalam menjalankan usaha perlu mengenali dan memahami diri perusahaan agar siap menghadapi dan memenangkan persaingan dengan para kompetitor. Penentuan strategi tersebut dapat dilakukan dengan analisis IFAS dan EFAS serta analisis SWOT untuk mengetahui apa yang menjadi kekuatan dan kelemahan perusahaan serta peluang dan ancaman yang harus dihadapi oleh perusahaan. Tujuan dari penelitian ini adalah untuk menganalisa faktor-faktor yang menjadi kekuatan, kelemahan, peluang dan ancaman bagi perusahaan serta menentukan strategi apa yang harus dilakukan untuk mengatasi pasang surutnya penjualan dengan menggunakan analisis IFAS, EFAS dan SWOT. Metode yang digunakan dalan penelitian ini adalah metode penelitian deskriptif. Data dalam penelitian ini diperoleh dari data primer dan hasil dari observasi, studi dokumentasi serta wawancara dengan informan penelitian yaitu manajer, karyawan dan konsumen. Hasil penelitiann menunjukkan bahwa posisi Q-Milk berada pada kuadran II, hal ini menunjukkan bahwa perusahaan menggunakan kekuatan dalam menghadapi berbagai ancaman. Berdasarkan analisis SWOT maka perusahaan dapat menggunakan strategi Diversifikasi dalam menjalankan usahanya. Dimana perusahaan dituntut untuk melakukan perubahan guna menutup kelemahan dan mengejar peluang yang ada, Hal yang harus dilakukan perusahaan yaitu : Pertahankan harga jual, lakukan inovasi dan terus ciptakan produk yang unik dan menarik, pertahankan kemasan produk sehingga menjadi ciri khas, tingkatkan kualitas produk, tingkatkan kegiatan promosi, memperluas wilayah distribusi agar produk Q-Milk lebih dikenal oleh masyarakat luas sehingga dapat memanfaatkan peluang yang ada.
\end{abstract}

Kata Kunci : Analisis IFAS dan EFAS, Analisis SWOT

\begin{abstract}
Q-Milk is a business engaged in the field of fresh and healthy drinks in the area Cilodong Depok. The resulting product is pure milk Q-Milk with various flavor variants without preservatives. In running the business need to recognize and understand the company's self in order to be ready to face and win the competition with the competitors. Determination of these strategies can be done by IFAS and EFAS analysis and SWOT analysis to find out what the strengths and weaknesses of the company and the opportunities and threats that must be faced by the company. The purpose of this study is to analyze the factors that become the strengths, weaknesses, opportunities and threats for the company and determine what strategies should be done to overcome the ebb and flow sales using analysis IFAS, EFAS and SWOT. The method used in this research is descriptive research method. The data in this research is obtained from primary data and result from observation, documentation study and interview with informant of research that is manager, employee and consumer. The results show that Q-Milk positions are in quadrant II, indicating that firms use strength in facing various threats. Based on SWOT analysis, the company can use Diversification strategy in running its business. Where the company is required to make changes to cover the weaknesses and pursue opportunities that exist, Things to do company that is: Keep the selling price, innovate and continue to
\end{abstract}


create unique and interesting products, keep the product packaging so that it becomes characteristic, improve product quality, Promotional activities, expanding the distribution area so that Q-Milk products are better known by the public so they can take advantage of the opportunities.

\section{Keywords: IFAS and EFAS Analysis, SWOT Analysis}

\section{Naskah diterima : 20 September 2017, Naskah dipublikasikan : 15 April 2018}

\section{PENDAHULUAN}

Laju pertumbuhan penduduk dapat menyebabkan bertambahnya kebutuhan pangan masyarakat untuk kelangsungan hidupnya. Setiap tahun bahkan setiap hari jumlah penduduk Indonesia terus bertambah oleh sebab itu ketersediaan pangan perlu ditingkatkan agar kebutuhan tersebut dapat terpenuhi yang sesuai dengan jumlah penduduk. Di samping itu pangan haruslah mengandung gizi yang tinggi seperti empat sehat lima sempurna sebagaimana yang dicetuskan oleh Prof. Poerwo Soedarmo yang merupakan semboyan dalam meningkatkan kesehatan masyarakat. Empat sehat meliputi makanan pokok, lauk pauk, sayur dan buah-buahan serta disempurnakan dengan yang ke lima yaitu susu. Menurut Syarief dan Sumoprastowo (1990) Susu merupakan komoditas dari perternakan yang mengandung gizi tinggi karena mengandung protein, lemak dan hidrat arang yang seimbang, mengandung banyak vitamin dan mineral, mengandung cukup banyak asam amino essensial dan non essensial, mempunyai nilai hayati yang hampir sama dengan susu ibu.

Oleh karena itu salah satu usaha kecil di kota Depok Jawa Barat Tepatnya di daerah Cilodong jalan Kemang Raya terdapat salah satu unit usaha yang terus mengembagkan minuman segar berbahan dasar susu murni dengan brand Q-Milk. Menurut ibu Sri (Pemilik) susu murni mempunyai rasa yang sangat khas yang membuat orang tidak terlalu menyukainya, untuk itu agar susu murni disukai oleh anak-anak hingga dewasa maka ditambahkanlah aneka varian rasa sehingga terciptalah susu murni dengan berbagai macam varian rasa.

Q-Milk adalah brand dari salah satu olahan susu murni dengan berbagai varian rasa terus berharap agar produknya dapat diterima oleh para konsumen dan terjual sesuai dengan target yang telah ditentukan sehingga omset perusahaan terus meningkat, namun beberapa bulan terakhir penjualan mengalami pasang surut yang berakibat menurunya omset perusahaan sebagaimana tergambar pada grafik berikut:

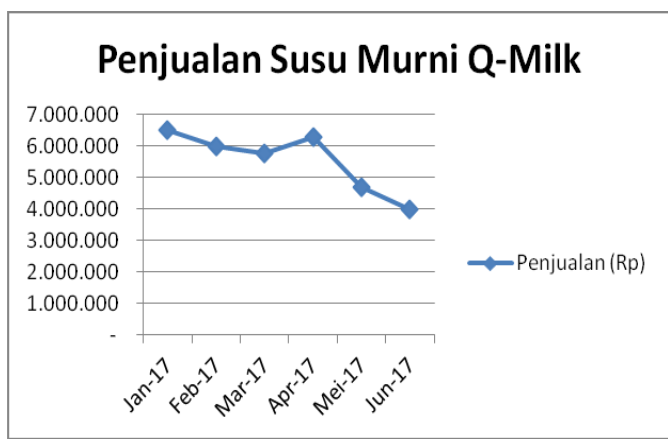

Sumber : Laporan Penjualan

Gambar 1. Grafik Penjualan Susu Q-Milk

Periode Januari - Juni 2017

Dengan memperhatikan grafik penjualan perusahaan yang terus mengalami penurunan dan perusahaan belum menerapkan strategi tertentu dalam menjalankan usahanya sehingga penulis akan menggunakan analisa SWOT. Menurut Galavan (2014) analisa SWOT adalah analisis yang digunakan untuk menentukan strategi yang tepat untuk diterapkan perusahaan berdasarkan keadaan publik dan pasar, dimana peluang dan ancaman digunakan untuk mengidentifikasi lingkungan eksternal perusahaan dan membandingkannya dengan kekuatan dan kelemahan yang didapatkan melalui analisis linkungan internal. Berdasarkan hal tersebut diatas maka tujuan dari penelitian ini adalah untuk menganalisa faktor internal dan eksternal yaitu faktor kekuatan, kelemahan, peluang dan ancaman bagi perusahaan serta menentukan strategi apa 
yang harus dikembangkan oleh perusahaan dengan menggunakan analisa SWOT. Berdasarkan hal tersebut maka penulis tertarik untuk melakukan penelitian pada usaha susu murni Q-Milk dengan judul "Analisa SWOT dalam menentukan strategi bisnis susu murni QMilk".

\section{KAJIAN LITERATUR \\ Penjualan}

Penjualan adalah bagaimana cara menciptakan hubungan jangka panjang dengan pelanggan melalui produk atau jasa perusahaan. Menurut Kartajaya (2006) penjualan berarti sebuah taktik yang dapat mengintegrasikan perusahaan, pelanggan, dan relasi antara keduanya. Sedangkan menurut Moekijat (2000) penjualan dapat juga diartikan suatu kegiatan yang ditujukan untuk mencari pembeli, mempengaruhi dan memberi petunjuk agar pembeli dapat menyesuaikan kebutuhannya dengan produk yang ditawarkan serta mengadakan perjanjian mengenai harga yang menguntungkan bagi kedua belah pihak.

Didalam melakukan kegiatan penjualan diperlukan suatu strategi agar dapat mencapai sasaran yang tepat. Menurut Swasta (2001) Strategi adalah suatu rencana yang diutamakan untuk mencapai tujuan tersebut. Jadi strategi adalah usaha yang disatukan, menyeluruh, terpadu yang mengaitkan keunggulan strategi perusahaan dengan tantangan lingkungan dan yang dirancang untuk memastikan bahwa tujuan utama perusahaan dapat dicapai melalui pelaksanaan yang tepat dalam perusahaan.

\section{SWOT}

SWOT adalah akronim untuk kekuatan (Strenghts), kelemahan (Weakness), peluang (Oppurtunities) dan ancaman (Threats) dari lingkungan eksternal perusahaan. Menurut Jogiyanto (2005) SWOT digunakan untuk menilai kekuatan-kekuatan dan kelemahankelemahan dari sumber daya yang dimiliki perusahaan dan kesempatankesempatan eksternal dan tantangantantangan yang dihadapi.
Menurut David (2006) semua organisasi memiliki kekuatan dan kelemahan dalam area fungsional bisnis. Tidak ada perusahaan yang sama kuatnya atau lemahnya dalam area bisnis. Kekuatan/kelemahan internal digabungkan dengan peluang/ancaman dari eksternal dan pernyataan misi yang jelas menjadi dasar untuk penetapan tujuan dan strategi . Tujuan dan strategi ditetapkan dengan maksud memanfaatkan kekuatan internal dan mengatasi kelemahan.

Berikut penjelasan SWOT menurut David (2006) yaitu:

\section{Kekuatan (Strenghts)}

Kekuatan adalah sumber daya, keterampilan-keterampilan atau keunggulan-keunggulan lain yang berhubungan dengan para pesaing perusahaan dan kebutuhan pasar yang dapat dilayani oleh perusahaan yang diharapkan dapat dilayani. Kekuatan adalah kompetisi khusus yang dapat memberikan keunggulan kompetitif bagi perusahaan di pasar.

\section{Kelemahan (Weakness)}

Kelemahan adalah keterbatasan atau kekurangan dalam sumber daya , keterampilan, dan kapabilitas yang secara efektif menghambat kinerja perusahaan. Keterbatasan tersebut dapat berupa fasilitas, sumber daya keuangan, kemampuan manajemen dan keterampilan pemasaran dpat merupakan sumber kelemahan dari perusahaan.

\section{Peluang (Opportunities)}

Peluang adalah situasi penting yang menguntungkan dalam lingkungsn perusahaan. Kecenderungankecenderungan penting merupakan salah satu sumber peluang, seperti perubahan teknologi dan meningkatnya hubunagan atara perusahaan dengan pembeli atau pemasok merupakan gambaran peluang bagi perusahaan.

\section{Ancaman (Threats)}

Ancaman adalah situasi penting yang tidak menguntungkan dalam lingkungan perusahaan. Ancaman merupakan pengganggu utama dalam posisi sekarang atau yang diinginkan oleh perusahaan. Adanya peraturan pemerintah yang baru 
atau yang direvisi dapat merupakan acaman bagi kesuksesan perusahaan.

Menurut Farrel dan Harline (2005) fungsi analisis SWOT adalah untuk mendapatkan informasi dari analisis situasi dan memisahkannya dalam pokok persoalan internal (kekuatan dan kelemahan) dan pokok persoalan eksternal (peluang dan ancaman).

Analisis SWOT tersebut akan menjelaskan apakah informasi tersebut berindikasi sesuatu yang akan membantu perusahaan mencapai tujuannya atau memberikan indikasi bahwa terdapat rintangan yang harus dihadapi atau diminimalkan untuk memenuhi pemasukan yang diinginkan. Analisis SWOT dapat digunakan dengan berbagai cara untuk meningkatkan analisis dalam usaha penetapan strategi. Umumnya yang sering digunakan adalah sebagai kerangka /panduan sistematis dalam diskusi untuk membahas kondisi alternative dasar yang mungkin menjadi pertimbangan perusahaan.

\section{Matrik EFAS dan IFAS}

Menurut Rangkuti (2014) analisis SWOT membandingkan antara faktor eksternal peluang dan ancaman dengan faktor internal kekuatan dan kelemahan. Faktor internal dimasukan ke dalam matrik IFAS (Internal Factor Analysis Summary). Faktor eksternal dimasukan ke dalam EFAS (Eksternal Factor Analysis Summary). Berikut tabel matrik faktor strategi eksternal dan internal.

Tabel 1

Matrik Faktor Strategi Eksternal (EFAS)

\begin{tabular}{|l|c|c|c|}
\hline $\begin{array}{l}\text { Faktor strategi } \\
\text { ekternal }\end{array}$ & Bobot & $\begin{array}{l}\text { Rati } \\
\text { ng }\end{array}$ & $\begin{array}{c}\text { Bobot X } \\
\text { Rating }\end{array}$ \\
\hline $\begin{array}{l}\text { Peluang } \\
\text { (Opportunity) }\end{array}$ & $\mathbf{X}$ & $\mathbf{X}$ & $\mathbf{X}$ \\
\hline Jumlah & $\mathbf{X}$ & $\mathbf{X}$ & $\mathbf{X}$ \\
\hline $\begin{array}{l}\text { Ancaman } \\
\text { (Threats) }\end{array}$ & $\mathbf{X}$ & $\mathbf{X}$ & $\mathbf{X}$ \\
\hline Jumlah & $\mathbf{X}$ & $\mathbf{X}$ & $\mathbf{X}$ \\
\hline Total & $\mathbf{X}$ & $\mathbf{X}$ & $\mathbf{X}$ \\
\hline
\end{tabular}

Sumber : Rangkuti (2014)
Tabel 2

Matrik Faktor Strategi Internal (IFAS)

\begin{tabular}{|l|c|c|c|}
\hline $\begin{array}{l}\text { Faktor } \\
\text { strategi } \\
\text { Internal }\end{array}$ & Bobot & Rating & $\begin{array}{c}\text { Bobot } \\
\mathbf{X} \\
\text { Rating }\end{array}$ \\
\hline $\begin{array}{l}\text { Kekuatan(Stre } \\
n g h t s)\end{array}$ & $\mathbf{X}$ & $\mathbf{X}$ & $\mathbf{X}$ \\
\hline Jumlah & $\mathbf{X}$ & $\mathbf{X}$ & $\mathbf{X}$ \\
\hline $\begin{array}{l}\text { Kelemahan } \\
\text { (Weaknes) }\end{array}$ & $\mathbf{X}$ & $\mathbf{X}$ & $\mathbf{X}$ \\
\hline Jumlah & $\mathbf{X}$ & $\mathbf{X}$ & $\mathbf{X}$ \\
\hline Total & $\mathbf{X}$ & $\mathbf{X}$ & $\mathbf{X}$ \\
\hline
\end{tabular}

Sumber : Rangkuti (2014)

Setelah matrik faktor strategi internal dan eksternal selesai disusun kemudian hasilnya dimasukkan ke dalam matrik SWOT (Strenght, Weakness, Opportunity and Threat) untuk menentukan strategi kompetitif perusahaan.

\section{Matriks SWOT}

Menurut David (2012) matrik SWOT adalah sebuah alat penentuan yang sangat penting dimana hal itu akan membantu mengembangkan empat strategi : SO (Strenght Opportunities), WO (Weakness Opprtunities), ST (Strenght threat), WT (Weakness threat).

Menurut Rangkuti (2014) berdasarkan matriks TOWS atau SWOT terdapat empat kuadrat berbeda, yaitu:

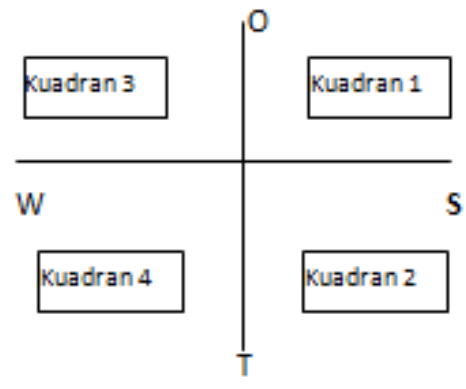

Sumber : Rangkuti (2014)

Gambar 2. Matrik TOWS atau SWOT

1. Kuadran 1 SO (Strenght Opportunity) merupakan situasi yang sangat menguntungkan. Perusahaan yang ada dikuadran ini memiliki peluang dan kekuatan sehingga dapat memanfaatkan peluang yang ada. Pada kuadran pertama strategi yang dapa diambil adalah strategi agresif. Strategi agresif adalah strategi yang 
mendukung perusahaan untuk terus memaksimalkan kekuatan serta peluang yang ada untuk terus maju dan meraih kesuksesan yang lebih besar.

2. Kuadran 2 ST (Strenghtt - Threat), perusahaan yang berada dikuadran ini menghadapi banyak ancaman namun masih mempunyai kekuatan dari segi internal . pada kuadran kedua strategi yang dapat diambil adalah strategi diversifikasi. Strategi diversifikasi adalah strategi yang menuntut perusahaan untuk melakukan perubahan guna menutup kelemahannya dan mengejar peluang yang tersedia.

3. Kuadran 3 WO (Weakness Opportunity), diposisi ini sebenarnya perusahaan mempunyai peluang yang sangat besar. Tetapi dilain pihak dia mempunyai banyak kendala internal. Pada kuadran ketiga sgtrategi yang dapat diambil adalah strategi turnaround. Strategi turn-around adalah strategi yang mendukung perusahaan untuk memaksimalkan kekuatan yang ada untuk mengubah arah usaha dikarenakan saat ini sudah banyak sekali ancaman yang dapat menghancurkan perusahaan.

4. Kuadran 4 WT (weakness-Threat), perusahaan berada diposisi yang sangat tidak menguntungkan. Perusahaan ini menghaddapi banyak ancaman dan kelemahan internal. Sedangkan pada kuadran keempat strategi yang dapat diambil adalah strategi disfentif. Strategi disfentif adalah strategi yang mendukung perusahaan untuk terus mempertahankan posisi perusahaan dengan segala kemampuan yang ada. Hal itu terjadi karena banyak sekali ancaman dari pihak dalam maupun luar perusahaan.

\section{METODE PENELITIAN \\ Jenis Penelitian}

Metode yang digunakan dalam penelitian ini adalah metode deskriptif. Menurut Indriantoro dan Supomo (2002) studi deskriptif adalah penelitian terhadap fenomena atau populasi tertentu yang diperoleh peneliti dari subyek berupa: individu, organisasional, industri perspektif yang lain.

\section{Operasional Variabel}

Agar lebih memahami definisi variabel yang diteliti, berikut ini definisi operasional dari masing-masing variabel analisi SWOT yang digunakan dalam penetelitian.

1. Kekuatan (Strenght) adalah kekuatan yang dimiliki oleh perusahaan dalam menghadapi peluang.

2. Kelemahan (Weakness) adalah suatu kelemahan yang dimiliki oleh perusahaan atau kekurangan dalam keterampilan yang menghambat kinerja perusahaan.

3. Peluang (Opportunity) adalah suatu peluang yang dimiliki oleh perusahaan yang menguntungkan.

4. Ancaman (Threat) adalah ancaman yang dihadapi oleh perusahaan.

\section{Teknik Pengumpulan Data}

Data dalam penelitian ini diperoleh dari data primer dan hasil observasi, studi dokumentasi serta wawancara dengan informan penelitian yaitu Manajer, karyawan dan konsumen.

\section{Metode Analisis Data}

Data dalam penelitian ini akan di analisa dengan mengunakan analisis SWOT dengan membandingkan antara faktor eksternal peluang dan ancaman dengan faktor internal kekuatan dan kelemahan untuk mengetahui apa yang menjadi kekuatan dan kelemahan perusahaan, peluang dan ancaman yang harus dihadapi serta strategi apa yang harus diambil oleh perusahaan dalam menjalankan usahanya.

\section{PEMBAHASAN}

\section{Deskripsi Analisa SWOT}

Dalam penelitian ini terdapat dua factor dalam analisa SWOT yaitu faktor Ekternal dan faktor Internal. Faktor-faktor ekternal merupakan peluang dan ancaman yang sedang dihadapi oleh susu murni QMilk adalah sebagai berikut:

a. Peluang

1) Produk baru

Susu murni dengan merk Q-Milk merupakan brand baru yang disajikan dengan berbagai macam 
varian rasa sehingga banyak dicari oleh konsumen.

2) Permintaan konsumen

Hadirnya susu murni Q-Milk ditengah-tengah masyarakat dengan berbagai macam varian rasa dengan tanpa bahan pengawet membuat QMilk disukai oleh semua usia.

3) Trend pola hidup sehat

Kemajuan jaman yang semakin modern dan banyaknya penyakit yang datang karena berbagai macam makanan dan minuman yang mengandung bahan pengawet sehingga membuat para konsumen mencari makanan dan minuman yang alami tanpa bahan pengawet demi menjaga kesehatan diri meka dan keluarga.

4) Pertumbuhan penduduk

Pertumbuhan penduduk yang terus bertambah setiap tahunnya diharapkan produk Q-Milk semakin dicari,

b. Ancaman

1) Kenaikan Tarif BBM dan Listrik Dengan meningkatnya tarif BBM dan Listrik dari tahun ketahun tentunya menyebabkan meningkatnya harga bahan baku yang dibutuhkan sehingga akan mempengaruhi tingkat penjualan QMilk

2) Perijinan BPOM yang sulit didapat Sulitnya mengurus ijin dari BPOM dikhawatirkan akan mengakibatkan tingkat kepercayaan konsumen terhadap produk Q-Milk menurun.

3) Pendatang baru

Dengan semakin meningkatnya pertumbuhan ekonomi dan penduduk tidak menutup kemungkinan akan muncul pendatang baru sehingga mengakibatkan adanya persaingan yang semakin ketat.

4) Persaingan yang kompetitif

Adanya para pesaing baru dikhawatirkan akan membuat terjadinya persaingan dalam menetukan harga jual.

Sedangkan untuk Faktor-faktor internal merupakan kekuatan dan kelemahan yang ada pada Susu Murni Q-Milk. a. Kekuatan

1) Harga terjangkau

Harga jual susu murni dengan

berbagai macam varian rasa

sangatlah terjangkau yaitu

berkisaran Rp 10.000/botol dengan isi $250 \mathrm{ml}$

2) Inovasi dan keunikan produk

Perusahaan selalu berinovasi dengan menyajikan berbagai macam varian rasa.

3) Kemasan yang menarik

Produk dikemas dengan menggunakan botol yang menyerupai botol Dot dengan isi bersih $250 \mathrm{ml}$, praktis dan aman.

4) kualitas produk

kualitas produk terjamin kebersihannya dan keaslian dari susunya karena bahan baku diperoleh langsung dari peternak dan telah di pasteurisasi .

b. Kelemahan

1) Promosi yang kurang maksimal

Untuk mencapai konsumen perusahaan belum terlalu maksimal dalam menggunakan sarana promosi, perusahaan masih menggukan X-Bunner, Facebook, Twiter dalam memasarkan produk.

2) Distribusi yang kurang meluas

Karena belum maksimalnya perusahaan dalam mengunakan media promosi sehingga pendistribusianpun belum dapat menjangkau masyarakat luar.

3) Ketahanan produk Susu murni Q-Milk dibuat tanpa menggunakan bahan pengawet untuk menjaga kemurniannya sehingga sangat rentan rusak.

4) Brand masih baru

Q-Milk merupakan brand susu murni yang masih tergolong baru sehingga belum terlalu pamiliar ditenggah-tengah masyarakat luas.

\section{Tabel IFAS dan EFAS}

Dari deskripsi analisa SWOT diatas selanjutnya dilakukan analisis dengan menggunakan table IFAS dan EFAS. 
Tabel 3

Tabel IFAS (Internal Factor Analysis Summary)

\begin{tabular}{lccc}
\hline $\begin{array}{l}\text { Faktor } \\
\text { strategi } \\
\text { internal }\end{array}$ & Bobot & Rating & $\begin{array}{c}\text { Bobot X } \\
\text { Rating }\end{array}$ \\
\hline Kekuatan (Strenghts) & & \\
\hline $\begin{array}{l}\text { Harga } \\
\text { terjangkau }\end{array}$ & 0.14 & 3 & 0.42 \\
\hline $\begin{array}{l}\text { Iinovasi dan } \\
\text { keunikan } \\
\text { produk }\end{array}$ & 0.13 & 4 & 0.52 \\
\hline $\begin{array}{l}\text { Kemasan } \\
\text { yang } \\
\text { menarik }\end{array}$ & 0.09 & 4 & 0.36 \\
\hline $\begin{array}{l}\text { Kualitas } \\
\text { produk }\end{array}$ & 0.08 & 4 & 0.32 \\
\hline Sub total & & & $\mathbf{1 . 6 2}$ \\
\hline $\begin{array}{l}\text { Kelemahan }(\text { Weaknes) } \\
\text { Promosi } \\
\text { yang kurang } \\
\text { maksimal }\end{array}$ & 0.13 & 2 & 0.26 \\
\hline $\begin{array}{l}\text { Distribusi } \\
\text { yang kurang } \\
\text { meluas }\end{array}$ & 0.21 & 2 & 0.42 \\
\hline $\begin{array}{l}\text { Kahanan } \\
\text { produk }\end{array}$ & 0.11 & 2 & 0.22 \\
\hline $\begin{array}{l}\text { Brand masih } \\
\text { baru }\end{array}$ & 0.11 & 2 & 0.22 \\
\hline Sub total & 1 & $\mathbf{1 . 1 2}$ \\
\hline \begin{tabular}{l} 
Total \\
\hline
\end{tabular} & & & \\
\hline
\end{tabular}

Faktor kekuatan dan kelemahan dalam table IFAS tersebut diperoleh dari hasil wawancara penulis dengan manajer, karyawan dan konsumen. Penentuan bobot dilakukan oleh informan. Penentuan peringkat dilakukan oleh penulis sesuai dengan keadaan perusahaan. Untuk menentukan skor bobot adalah dengan cara bobot tiap indikator dikalikan dengan peringkat tiap indikator, kemudian tiap indikator dari faktor internal dan eksternal dijumlah dan dihitung selisih antara kedua faktor tersebut. Table 1 menunjukkan nilai kekuatan lebih besar 0,5 dibanding nilai kelemahan yang dimilikiperusahaan. Hal tersebut menunjukkan bahwa kekuatan lebih besar daripada kelemahan yang dimiliki perusahaan.

Setelah melakukan analisis faktor internal, selanjutnya dilakukan analisis faktor eksternal sebagai berikut:
Tabel 4

Tabel EFAS (External Factor Analysis Summary)

\begin{tabular}{lccc}
\hline $\begin{array}{l}\text { Faktor } \\
\text { strategi } \\
\text { ekternal }\end{array}$ & Bobot & Rating & $\begin{array}{c}\text { Bobot X } \\
\text { Rating }\end{array}$ \\
\hline $\begin{array}{l}\text { Peluang (Opportunity) } \\
\text { Produk baru }\end{array}$ & 0.11 & 3 & 0.33 \\
\hline $\begin{array}{l}\text { Permintaan } \\
\text { konsumen }\end{array}$ & 0.08 & 4 & 0.32 \\
\hline $\begin{array}{l}\text { Trend pola } \\
\text { hidup sehat }\end{array}$ & 0.13 & 4 & 0.52 \\
\hline $\begin{array}{l}\text { Pertumbuhan } \\
\text { penduduk }\end{array}$ & 0.18 & 3 & 0.54 \\
\hline Sub total & & & $\mathbf{1 . 7 1}$ \\
\hline Ancaman (Threats) & & & \\
\hline $\begin{array}{l}\text { Kenaikan tarif } \\
\text { BBm dan } \\
\text { Listrik }\end{array}$ & 0.09 & 3 & 0.27 \\
\hline $\begin{array}{l}\text { Perijinan } \\
\text { BPOM yang } \\
\text { sulit }\end{array}$ & 0.15 & 4 & 0.6 \\
\hline $\begin{array}{l}\text { Pendatang baru } \\
\text { Persaingan } \\
\text { yang kompetitif }\end{array}$ & 0.18 & 4 & 0.72 \\
\hline Sub total & & 3 & 0.24 \\
\hline \begin{tabular}{l} 
Total \\
\hline
\end{tabular} & & & $\mathbf{1 . 8 3}$ \\
\hline
\end{tabular}

Table 4 merupakan analisis terhadap faktor eksternal dengan menggunakan analisis EFAS (Ekternal Factor Analysis Summary) dimana nilai ancaman lebih besar 0,12 dibanding nilai peluang. Hal tersebut menunjukkan bahwa ancaman yang ada lebih besar dibandingkan dengan peluang yang tersedia.

Setelah menganalisa faktor internal dan eksternal langkah selanjutnya adalah memasukkan nilai selisih dari faktor Kekuatan dan Kelemahan $(0,5)$ serta Peluang dan Ancaman (-0,12) pada kuadran matrik SWOT sebagimana tampak pada gambar 3 berikut: 


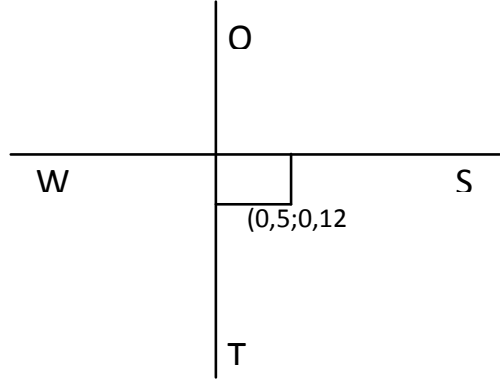

Sumber: Data diolah Gambar 3

Matriks SWOT Bisnis Susu Murni Q-Milk

Dari matrik SWOT pada gambar 3 diketahui bahwa Q-Milk berada pada kuadran II yakni kuadran diantara kekuatan dan ancaman sehingga strategi yang dapat digunakan oleh perusahaan adalah strategi diversifikasi dimana perusahaan dituntut untuk melakukan perubahan guna menutup kelemahan dan mengejar peluang yang ada. Dengan mengetahui posisi perusahan berdasarkan analisis matrik SWOT maka perusahaan dapat mengambil suatu keputusan dalam menjalankan usaha susu murni Q-Milk yaitu : Pertahankan harga jual, lakukan inovasi dan terus ciptakan produk yang unik dan menarik, pertahankan kemasan produk sehingga menjadi ciri khas, tingkatkan kualitas produk, tingkatkan kegiatan promosi, memperluas wilayah distribusi agar produk Q-Milk lebih dikenal oleh masyarakat luas sehingga dapat memanfaatkan peluang yang besar.

\section{PENUTUP}

Berdasarkan hasil penelitian yang telah dilakukan terhadap faktor internal dan eksternal dengan menggunakan analisis SWOT dapat diketahui bahwa Q-Milk berada diantara kuadran kekuatan dan ancaman sehingga perusahaan dapat menggunakan strategi diversifikasi dimana perusahaan dituntut untuk melakukan perubahan guna menutup kelemahan dan mengejar peluang yang tersedia dengan cara mempertahankan harga jual, melakukan inovasi dan ciptakan produk yang unik dan menarik, pertahankan kemasan produk sehingga menjadi ciri khas, meningkatkan kualitas produk, meningkatkan kegiatan promosi, memperluas wilayah distribusi agar produk Q-Milk lebih dikenal oleh masyarakat luas sehingga dapat memanfaatkan peluang yang besar

Saran yang dapat disampaikan oleh penulis kepada perusahaan dalam menjalankan kegiatan usahanya adalah agar perusahaan lebih meningkatkan kegiatan promosi karena selama menjalankan usahanya perusahaan hanya mengandalkan promosi dari mulut ke mulut dan spanduk serta X-Bunner yang ada. Sedangkan pemerintah kota depok banyak sekali menyediakan kegiatan UMKM sebagai sarana untuk promosi, agar dapat mengikuti kegiatan yang diadakan oleh perintah kota Depok terlebih dahulu Q-Milk harus bergabung dengan komunitas UMKM kota Depok. Penulis menyadari bahwa penelitian ini masih jauh dari kata sempurna untuk itu penulis menyarankan bagi peneliti selanjutnya sebaiknya menambah item lainnya dalam menentukan faktor eksternal dan internal agar lebih dapat diketahui strategi apa saja yang harus dilakukan oleh Q-Milk dalam menjalankan usahanya agar dapat bertahan ditengah persaingan usaha.

\section{REFERENSI}

David, Fred R. 2006. Manajemen Strategi. Edisi Sepuluh. Jakarta: Salemba Empat.

David, Fred R. 2012. Konsep Manajemen Strategi. Jakarta: Salemba Empat.

Farrel, O.C dan D, Harline. 2005. Marketing strategy. South Western : Thomson Corporation

Galavan, R. (2014). Doing Business Strategy. Ireland: NuBooks.

Indriantoro, Nur dan Supomo, Bambang. 2002. Metodologi Penelitian Bisnis. Edisi Pertama. Yogyakarta: BPFE

Jogiyanto. 2005. Sistem Informasi Strategik Untuk Keunggulan Kompetitif. Yogyakarta: Andi Ofset.

Kartajaya, Hermawan. 2006. Hermawan Kartajaya On Marketing. Jakarta : PT. Gramedia

Moekijat. 2000. Kamus Manajemen. Bandung : CV. Mandar Maju 
Rangkuti, F. 2014. Analisis SWOT: Teknik Membedah Kasus Bisnis.Jakarta:

Gramedia Pustaka utama.

Swasta, Basu dan Irwan. 2001. Manajemen Pemasasran Modern. Edisi Kedua. Yogyakarta: Liberty.

Syarief, M. Zein dan C.D.A. Sumoprastowo. 1990. Ternak Perah. Jakarata: CV Yasaguna.

\section{BIODATA PENULIS}

Nama saya Kasmanto Miharja, SE, MM lahir di Tanjung Baru - Palembang tanggal 03 Mei 1979 agama Islam, mengajar di BSI sejak tahun 2010 Pendidikan S2 Universitas Mercu Buana Jakarta program study Manajemen Konsentrasi Pemasaran tahun 2013. Saya tertarik untuk melakukan penelitian dalam bidang pemasaran dan akuntansi. 